\title{
Advances on mechanics, design engineering and manufacturing
}

\author{
Gaetano Sequenzia ${ }^{1} \cdot$ Sergio Rizzuti ${ }^{2} \cdot$ Massimo Martorelli $^{3} \cdot$ Tommaso Ingrassia $^{4}$
}

Published online: 18 September 2018

(c) Springer-Verlag France SAS, part of Springer Nature 2018

The theme of the present editorial is dedicated to the "Advances on Mechanics, Design Engineering and Manufacturing" that emerge in different engineering and architectural fields.

The theme has been chosen as leitmotiv of a series of events that have been organized by three societies operating in Italy, Spain and France, respectively: ADM (Associazione nazionale Disegno e Metodi dell'ingegneria industriale), INGEGRAF (Asociación Española de Ingeniería Gráfica and AIP-PRIMECA (Ateliers Inter-établissements de Productique-Pôles de Resources Informatiques pour la MECAnique). Since 2014, a series of JCM conferences have been organized. JCM is the acronym of "Joint Conference on Mechanics, Design Engineering and Advanced Manufacturing".

During the last JCM conference that was held in Catania (Italy) on 14-16 September 2016, after a peer-reviewed process, 123 papers, mainly from academic institutions, have been accepted and presented in oral and poster sessions. The papers are collected in the volume [1].

JCM Conferences are characterized by a set of topics, that follow the general advances of the knowledge in the fields of interest of the three above-mentioned societies and that merge the general scope of IJIDeM, as presented in [2].

The topics of the 2016 edition of JCM Conference have been:

Sergio Rizzuti

sergio.rizzuti@unical.it

1 Dipartimento di Ingegneria Elettrica, Elettronica ed Informatica (DIEEI), University of Catania, Catania, Italy

2 Department of Mechanical, Energy and Management Engineering, University of Calabria, Ponte P. Bucci 46/C, Rende, CS, Italy

3 Department of Industrial Engineering, University of Naples Federico II, P.le V. Tecchio 80, Naples, Italy

4 Dipartimento dell'Innovazione Industriale e Digitale Ingegneria Chimica, Gestionale, Informatica, Meccanica, Università degli Studi di Palermo, Viale delle Scienze, Palermo, Italy
- Integrated Product and Process Design

- Product Manufacturing and Additive Manufacturing

- Engineering Methods in Medicine

- Nautical, Aeronautics and Aerospace Design and Modelling

- Computer Aided Design and Virtual Simulation

- Education and Representation Techniques

- Geometric Product Characteristics

- Innovative Design

The 2018 edition of the JCM Conference, held in Cartagena (Spain) in the month of June, has update and lightly modified the field of interest also towards:

- Product Design and Development

- Computer-Aided Design and Interactive Design

- Manufacturing and Industrial Process Design

- Graphical Bioengineering

- Innovation

- Teaching and Learning

The 125 papers selected for the JCM 2018 Conference will appear as a volume of Lecture Notes in Mechanical Engineering edited by Springer.

The present Editorial would like to introduce the papers that, after a further selection on the basis of the higher ranking obtained by Scientific Committee of the JCM 2016 Conference, have been invited for publication on IJIDeM. They are related to some topics of the Conference. The papers appeared on the issues 2 and 3 of the 2018 IJIDeM volume.

The topic Integrated Product and Process Design has been studied by Barbieri et al. [3], Rizzuti and De Napoli [4].

The topic Product Manufacturing and Additive Manufacturing has been studied by Le et al. [5], Vitolo et al. [6].

The topic Engineering Method in Medicine has been investigated by several approaches, by Uccheddu et al. [7], Ingrassia et al. [8], Solaberrieta et al. [9], Íñiguez-Macedo et al. [10], Cappetti and Naddeo [11]. 
The topic Nautical, Aeronautics and Aerospace Design and Modelling has been studied by Mancuso et al. [12] and Cucinotta et al. [13].

The topic Computer Aided Design and Virtual Simulation has been investigated in Lapini et al. [14], Barbagallo et al. [15].

The topic Geometric Product Characteristics has been studied by Di Angelo et al. [16].

The topic Innovative Design collected, among others, the paper Feno et al. [17].

All who wish to submit a contribution on the topics reported above are invited to the JCM2020 edition that will take place in Aix-en-Provence (France) on June 2020, organized by S-mart (Systems, Manufacturing, Academics, Resources, Technologies), new name of the French society involved in the joint event.

\section{References}

1. Eynard, B., Nigrelli, V., Oliveri, S. M., Peris-Fajarnes, G., \& Rizzuti, S. (eds.) Advances on Mechanics, Design Engineering and Manufacturing: Proceedings of the International Joint Conference on Mechanics, Design Engineering \& Advanced Manufacturing (JCM 2016), 14-16 September, 2016, Catania, Italy. Springer (2016)

2. Fischer, X., Coutellier, D.: Editorial. IJIDeM 1, 1-4 (2007)

3. Barbieri, L., Bruno, F., Muzzupappa, M.: User-centered design of a virtual reality exhibit for archaeological museums. Int. J. Interact. Design Manuf. 12(2), 561-571 (2018)

4. Rizzuti, S., De Napoli, L.: An interactive robust design approach in product development. Int. J. Interact. Design Manuf. 12(2), 677-688 (2018)

5. Le, V.T., Paris, H., Mandil, G.: Extracting features for manufacture of parts from existing components based on combining additive and subtractive technologies. Int. J. Interact. Design Manuf. 12(2), 525-536 (2018)

6. Vitolo, F., Martorelli, M., Gerbino, S., Patalano, S., Lanzotti, A.: Controlling form errors in $3 \mathrm{D}$ printed models associated to size and position on the working plane. Int. J. Interact. Design Manuf. 12(3), 969-977 (2018)

7. Uccheddu, F., Carfagni, M., Governi, L., Furferi, R., Volpe, Y., Nocerino, E.: 3D printing of cardiac structures from medical images: an overview of methods and interactive tools. Int. J. Interact. Design Manuf. 12(2), 597-609 (2018)
8. Ingrassia, T., Nalbone, L., Nigrelli, V., Ricotta, V., Pisciotta, D.: Biomechanical analysis of the humeral tray positioning in reverse shoulder arthroplasty design. Int. J. Interact. Design Manuf. 12(2), 651-661 (2018)

9. Solaberrieta, E., Barrenetxea, L., Minguez, R., Iturrate, M., De Prado, I.: Registration of mandibular movement for dental diagnosis, planning and treatment. Int. J. Interact. Design Manuf. 12(3), 1027-1038 (2018)

10. Íñiguez-Macedo, S., Somovilla-Gómez, F., Lostado-Lorza, R., Corral-Bobadilla, M., Martínez-Calvo, M.Á., Sanz-Adán, F.: The process of designing a rotating platform artificial knee prosthesis with posterior stabilizers by finite element analysis. Int. J. Interact. Design Manuf. 12(3), 853-864 (2017)

11. Cappetti, N., Naddeo, A.: On methods to identify the symmetry line of human back. Int. J. Interact. Des. Manuf. (2018). https://do i.org/10.1007/s 12008-018-0503-7

12. Mancuso, A., Pitarresi, G., Tumino, D.: Using FEM simulation to predict structural performances of a sailing dinghy. Int. J. Interact. Design Manuf. 12(3), 811-822 (2018)

13. Cucinotta, F., Nigrelli, V., Sfravara, F.: Numerical prediction of ventilated planing flat plates for the design of air cavity ships. Int. J. Interact. Design Manuf. 12(2), 537-548 (2018)

14. Lapini, A., Borchi, F., Carfagni, M., Argenti, F.: Simulation and design of active control systems for acoustic pulse noise. Int. J. Interact. Design Manuf. 12(2), 573-584 (2018)

15. Barbagallo, R., Sequenzia, G., Cammarata, A., Oliveri, S.M., Fatuzzo, G.: Redesign and multibody simulation of a motorcycle rear suspension with eccentric mechanism. Int. J. Interact. Design Manuf. 12(2), 517-524 (2018)

16. Di Angelo, L., Di Stefano, P., Morabito, A.E.: Secondary features segmentation from high-density tessellated surfaces. Int. J. Interact. Design Manuf. 12(3), 801-809 (2018)

17. Feno, M.R., Martin, P., Daille-Lefevre, B., Etienne, A., Marsot, J., Siadat, A.: Safety of machinery: requirement specification based on functional need and work situations analysis. Int. J. Interact. Design Manuf. 12(3), 943-953 (2018)

Publisher's Note Springer Nature remains neutral with regard to jurisdictional claims in published maps and institutional affiliations. 